\title{
Effects of Methionine Supplementation in Low-Protein Diets and Subsequent Re-feeding on Growth Performance, Liver and Serum Lipid Profile, Body Composition and Carcass Quality of Broiler Chickens at 42 Days of Age
}

\author{
Rattana Nukreaw ${ }^{1}$, Chaiyapoom Bunchasak ${ }^{1}$, Kanchana Markvichitr ${ }^{1}$, Apassara Choothesa ${ }^{2}$, \\ Somkiert Prasanpanich ${ }^{1}$ and Wiriya Loongyai ${ }^{1}$ \\ ${ }^{1}$ Department of Animal Science, Faculty of Agriculture, Kasetsart University, Bangkok, Thailand \\ ${ }^{2}$ Department of Physiology, Faculty of Veterinary Medicine, Kasetsart University, Bangkok, Thailand
}

\begin{abstract}
This study was conducted to evaluate the effects of adding methionine (Met) to low-protein diets and subsequent re-feeding on the growth performance, serum lipid profile, body composition and carcass quality in male broiler chicks during 1-42 days of age. During the starter-grower period (1-21 days of age), 800 male broiler chicks (Ross 308) were divided into 5 groups and given the following diets: 1) positive control diet (all nutrients meet the requirements of the strain), 2) negative control diet (low-protein diet in which all amino acids meet the requirements of the strain, except Met), 3) negative control diet supplemented with Met to meet the total sulfur amino acid (TSAA) requirement at 100\%, 4) negative control diet supplemented with Met to meet the TSAA requirement at 105\%, and 5) negative control diet supplemented with Met to meet the TSAA requirement at $110 \%$. During the finisher period (22-42 days of age), all groups were fed a diet containing the same nutrients and according to the recommendations for the strain. At Day 21, adding Met to the low-protein diet resulted in a similar body weight gain and feed conversion ratio (FCR) to that of the positive control group. Feed intake in the $105 \%$ TSAA group significantly increased compared to that in the positive control and negative control groups $(P<0.05)$. Met supplementation in the low-protein diet significantly improved the protein efficiency of chicks $(P<0.01)$, while Met deficiency increased feed cost per body weight gain $(P<0.01)$. Abdominal fat contained in chicks fed the low-protein diet was significantly increased, although Met supplementation slightly decreased the abdominal fat. In the 110\% TSAA group, triglyceride in serum was significantly increased $(P<0.01)$, while low density lipoprotein-cholesterol in serum was significantly depressed $(P<0.01)$. After the re-feeding phase (at Day 42 of age), the growth performance of the negative control group was still significantly poorer than that of other groups $(P<0.05)$. Adding Met to the low-protein diet significantly improved the protein efficiency ratio compared to the positive and negative control groups $(P<0.05)$. The body compositions and abdominal fat of broiler chickens did not significantly differ among the treatments $(P>0.05)$. The carcass yield, breast meat and wings of the $110 \%$ TSAA group were significantly higher than those of the negative control group ( $P$ $<0.05)$. The results indicate that reducing the protein concentration with Met supplementation during 1-21 days of age, then re-feeding with a conventional diet is an appropriated tool for improving overall protein utilization and slightly reduces the production cost.
\end{abstract}

Key words: body composition, carcass, chicks, compensatory, low-protein, methionine

J. Poult. Sci., 48: 229-238, 2011

\section{Introduction}

Feeding low-protein diets clearly reduces feed costs (Cauwenberghe and Burnham, 2001), and improves protein efficiency, whilst increasing fat accumulation (Faria Filho et al., 2003) and decreasing the growth performance

Received: July 8, 2010, Accepted: June 22, 2011

Released Online Advance Publication: July 25, 2011

Correspondence: C. Bunchasak, Department of Animal Science, Faculty of Agriculture, Kasetsart University, Bangkok, Thailand.

(E-mail: agrchb@hotmail.com) of broiler chickens (Leeson and Summers, 1991). The negative effects of using a low-protein diet can be prevented by adding supplementary synthetic amino acids to the diet to improve the amino acid pattern balance (Khajali and Moghaddam, 2006; Saki et al., 2007).

Methionine (Met) is the primary limiting amino acid in poultry diets, particular in a corn-soybean meal based diet (Jianlin et al., 2004). Several researches have reported that the requirement for this amino acid is substantial but variable as a result of changes in the genetics, nutrition and management of broiler chicks (Kalinowski et al., 
2003). Met acts as a lipotropic agent through its role as an amino acid in balancing protein, or through its role as a methyl donor and it is incorporated into carnitine and creatine (Kalinowski et al., 2003). Focusing on fat metabolism, Bunchasak (1997) showed that the serum triglyceride level tends to be decreased, and the breast meat triglyceride content is significantly reduced when Met is added to diets, thus Met may have the potential to disturb the ability of lipid transporters such as lipoproteins (liver into blood).

In terms of economic returns, a low-protein diet supplemented with synthetic amino acids is still less efficient than the conventional diet (Hussein et al., 2001). Improved growth performance due to amino acid supplementation can be inconsistent (Keshavarz and Austic, 2004), which may be due to several factors such as inadequate knowledge about essential amino acid requirements, the amino acid content of feed ingredients, the digestibility and bioavailability of amino acids in feed ingredients, and the proper ratio among essential amino acids in a low-protein diet. Moreover, Takahashi et al. (1994) reported that at 21 days of age, maximum performance cannot be achieved by feeding broilers a low-protein diet supplemented with amino acids, because young chicks are more sensitive to amino acid inadequacy than older birds. This means that sufficient amino acid intake during the starter period does not always achieve maximal growth performance, which depends on duration of feeding low-protein, age, degree of protein reduction as well as environmental conditions.

In light of the fact that many studies have reported improvements in feed efficiency during compensatory growth in restricted-refed broilers (Zubair and Leeson, 1996), the concept of feeding a low-protein diet with Met supplementation during the starter-grower period merits investigation along with associated compensatory responses in order to address the inconsistent effects of such a diet. Recently, moreover, Azarnik et al. (2010) recommended that supplementing a low-protein diet with amino acids during feed restriction may partially correct the depression in the growth performance of broiler after re-feeding.

Therefore, this study focused on the effects of Met supplementation in a low-protein diet during startergrower periods and consequent re-feeding during the finishing period on the growth performance, lipid profile, body composition and carcass yields of male broiler chickens.

\section{Materials and Methods}

\section{Animal and Managements}

Eight hundred male broiler chicks (Ross 308) were used in this trial. The study was conducted in the animal research station of the Department of Animal Science (Bangkok). The chicks were divided into 5 treatment groups and each treatment group consisted of 8 replications of 20 chicks each. The chicks were kept in floor pens $\left(0.09 \mathrm{~m}^{2}\right.$ floor space per bird) that were located in an evaporative cooling house system during 1-42 days of age. The temperature was set at $32^{\circ} \mathrm{C}$ at day-old and then was decreased by $1{ }^{\circ} \mathrm{C}$ every 3 days until a final temperature of $25^{\circ} \mathrm{C}$ was reached. The lighting management and vaccinations were provided according to commercial practice. Each pen was equipped with one hanging feeder and three nipple drinkers. The broiler chicks were allowed access to water and feed ad libitum throughout the experimental period.

\section{Experimental Design and Diet}

A completely randomized design was used. Five experimental diets (mash form) were provided as follows; 1) positive control diet (providing 22\% CP during 1-10 days of age and 21\% CP during 11-21 days of age; all nutrient requirements were adjusted as per strain recommendation), 2) negative control diet (providing 19\% and 18\% CP without Met supplementation, but other essential amino acids were according to strain requirements), 3) negative control diet supplemented with Met to meet TSAA requirement at $100 \%, 4)$ negative control diet supplemented with Met to meet TSAA requirement at $105 \%$, and 5) negative control diet supplemented with Met to meet TSAA requirement at $110 \%$. Except dietary $\mathrm{CP}$ and Met, all nutrients in low protein diets were formulated according to the recommendations of the strain. The broiler chicks were fed dietary treatments from 1 to 21 days of age. Subsequently, all chicks were fed a diet containing $19 \% \mathrm{CP}$ and 3,225 ME kcal/kg of energy (according to the recommendations of the strain) during the finisher period (22-42 days of age). The feed formulas and nutrients contained in the diet are shown in Table 1. The supplemented levels of Met are presented in Table 2. The total sulfur amino acid/Lysine and Met/Lysine ratio are shown in Table 3. The quantities of Met supplementation are shown in Table 4.

Feed samples were collected and subsequently ground using a 1-mm screen in a grinder. All diets were analyzed for protein and ether extract according to AOAC (2000) methods. The amino acid composition of positive control and negative control diets in starter and grower periods was analyzed by Amino Acids Analyzer (AminoTac JEOL model JLC-500/V [JEOL Ltd., Tokyo, Japan]).

\section{Growth Performance}

The body weight and feed intake of the chicks were measured weekly. Subsequently, protein intake, protein efficiency, ADG and FCR were calculated from these data. Feed cost per body weight gain was estimated from the value of FCR multiplied by feed cost. Mortality was checked daily for calculation of the mortality rate.

\section{Sampling Procedures}

At 21 days of age, after overnight feed deprivation, all chicks were weighed. Eight chicks (one chick per pen) were randomly selected from each treatment for collection of blood from the wing vein and then sacrificed using $\mathrm{CO}_{2}$ asphyxiation in an atmosphere of less than $2 \%$ oxygen (air displaced by $\mathrm{CO}_{2}$ ) for 1.5-2.0 min. Subsequently, the liver and abdominal fat (including fat surrounding gizzard, Cabel et al., 1987) of each bird were collected, weighed and stored at $-20^{\circ} \mathrm{C}$ until used for chemical analysis. 
Table 1. Composition of the experimental diets and chemical analysis

\begin{tabular}{|c|c|c|c|c|c|}
\hline \multirow[b]{2}{*}{ Ingredient } & \multicolumn{5}{|c|}{ Amount } \\
\hline & $\begin{array}{c}\text { Positive } \\
\text { control diet } \\
\text { (1-10 days) }\end{array}$ & $\begin{array}{c}\text { Negative } \\
\text { control diet } \\
\text { (1-10 days) }\end{array}$ & $\begin{array}{c}\text { Positive } \\
\text { control diet } \\
\text { (11-21 days) }\end{array}$ & $\begin{array}{c}\text { Negative } \\
\text { control diet } \\
(11-21 \text { days })\end{array}$ & $\begin{array}{c}\text { Conventional } \\
\text { diet } \\
\text { (22-42 days) }\end{array}$ \\
\hline & & & $(\%)$ & & \\
\hline Corn & 54.876 & 62.340 & 55.399 & 62.931 & 60.24 \\
\hline Rice bran oil & 1.703 & 1.001 & 4.002 & 3.277 & 3.29 \\
\hline Soybean meal & 36.194 & 28.593 & 34.172 & 26.572 & 25.43 \\
\hline Full fat soybean meal & 2.000 & 2.000 & 2.000 & 2.000 & 7.00 \\
\hline $\begin{array}{l}\text { Monodicalcium phosphate } \\
\text { (P 21\%, Ca 16\%) }\end{array}$ & 2.313 & 2.385 & 2.042 & 2.114 & 1.91 \\
\hline Lime stone & 1.310 & 1.330 & 1.176 & 1.196 & 1.13 \\
\hline Salt & 0.210 & 0.209 & 0.215 & 0.213 & 0.22 \\
\hline L-Lysine & 0.298 & - & 0.103 & - & - \\
\hline DL-methionine & 0.409 & - & 0.293 & - & 0.19 \\
\hline L-threonine & 0.088 & 0.213 & - & 0.118 & - \\
\hline Premix & 0.500 & 0.500 & 0.500 & 0.500 & 0.50 \\
\hline Sacox & 0.050 & 0.050 & 0.050 & 0.050 & 0.05 \\
\hline Antioxidant & 0.050 & 0.050 & 0.050 & 0.050 & 0.05 \\
\hline Corn starch & - & 1.329 & - & 0.980 & - \\
\hline Total & 100.00 & 100.00 & 100.00 & 100.00 & 100.00 \\
\hline Feed cost/kg (Thai Baht) & 16.22 & 14.88 & 16.25 & 15.11 & 15.90 \\
\hline \multicolumn{6}{|l|}{$\begin{array}{l}\text { Chemical composition, } \\
\text { calculated (analyzed) }\end{array}$} \\
\hline Crude protein $(\%)$ & $22.00(23.44)$ & $19.00(18.37)$ & $21.00(21.40)$ & $18.00(18.59)$ & $19.00(19.06)$ \\
\hline Energy (ME) kcal $/ \mathrm{kg}$ & 3,010 & 3,010 & 3,175 & 3,175 & 3,225 \\
\hline Ether extract $(\%)$ & $4.67(4.55)$ & $4.19(4.00)$ & $6.94(7.54)$ & $6.44(6.21)$ & $7.26(8.10)$ \\
\hline Calcium $(\%)$ & 1.00 & 1.01 & 0.90 & 0.91 & 0.85 \\
\hline Avail. phosphorus (\%) & 0.50 & 0.51 & 0.45 & 0.45 & 0.42 \\
\hline Lysine $(\%)$ & $1.44(1.40)$ & $1.02(1.06)$ & $1.23(1.40)$ & $0.96(0.96)$ & $1.02(1.05)$ \\
\hline Total sulfur amino acid $(\%)$ & $1.09(1.00)$ & $0.62(0.78)$ & $0.95(0.90)$ & $0.59(0.54)$ & $0.80(0.77)$ \\
\hline$*$ DL-methionine $(\%)$ & $0.74(0.63)$ & $0.30(0.25)$ & $0.61(0.51)$ & $0.29(0.24)$ & $0.48(0.43)$ \\
\hline Threonine $(\%)$ & $0.93(0.84)$ & $0.94(0.81)$ & $0.81(0.75)$ & $0.81(0.75)$ & $0.73(0.68)$ \\
\hline Arginine $(\%)$ & $1.52(1.46)$ & $1.30(1.22)$ & $1.45(1.42)$ & $1.22(1.15)$ & $1.29(1.24)$ \\
\hline Isoleucine $(\%)$ & $0.98(0.94)$ & $0.84(0.80)$ & $0.94(0.93)$ & $0.80(0.72)$ & $0.84(0.79)$ \\
\hline Leucine $(\%)$ & $1.84(1.81)$ & $1.64(1.59)$ & $1.77(1.77)$ & $1.58(1.48)$ & $1.65(1.60)$ \\
\hline Valine $(\%)$ & $1.07(1.05)$ & $0.93(0.93)$ & $1.02(1.06)$ & $0.88(0.84)$ & $0.93(0.92)$ \\
\hline
\end{tabular}

Premix: vitamin A 12,000,000 IU, vitamin D3 3,000,000 IU, vitamin E 15,000 mg, vitamin K3 1,500 mg, vitamin B1 1,500 mg, vitamin B2 5,500 mg, vitamin B6 2,000 mg, vitamin B12 $10 \mathrm{mg}$, nicotinic acid 25,000 mg, D-calcium pantothenate $12,000 \mathrm{mg}$, folic acid $500 \mathrm{mg}$, biotin $120 \mathrm{mg}$, manganese $80 \mathrm{~g}$, zinc $60 \mathrm{~g}$, iron $40 \mathrm{~g}$, copper $8 \mathrm{~g}$, iodine $0.05 \mathrm{~g}$, cobalt $0.10 \mathrm{~g}$, selenium 0.10 g; filler added to 1 ton.

* Synthetic DL-methionine was supplied by Sumitomo Chemical, Japan.

(...) Analytical analysis value.

Table 2. Dietary Met supplementation levels

\begin{tabular}{|c|c|c|c|c|c|}
\hline & \multirow{2}{*}{$\begin{array}{c}\text { Positive } \\
\text { control } \\
\text { diet }\end{array}$} & \multicolumn{4}{|c|}{ Negative control diet (Low-protein diets) } \\
\hline & & $\begin{array}{c}\text { Non- } \\
\text { addition }\end{array}$ & $\begin{array}{l}100 \% \\
\text { TSAA }\end{array}$ & $\begin{array}{l}105 \% \\
\text { TSAA }\end{array}$ & $\begin{array}{l}110 \% \\
\text { TSAA }\end{array}$ \\
\hline \multicolumn{6}{|c|}{ Starter period (1-10 days of age) } \\
\hline Met $(\mathrm{g} / 100 \mathrm{~kg}$ diet $)$ & 409 & - & 486 & 538 & 601 \\
\hline TSAA requirement $(\%)$ & 1.09 & 0.617 & 1.09 & 1.14 & 1.20 \\
\hline \multicolumn{6}{|c|}{ Grower period (11-21 days of age) } \\
\hline Met $(\mathrm{g} / 100 \mathrm{~kg}$ diet $)$ & 293 & - & 370 & 419 & 469 \\
\hline TSAA requirement $(\%)$ & 0.950 & 0.589 & 0.950 & 0.997 & 1.045 \\
\hline
\end{tabular}


Table 3. Total sulfur amino acid/lysine and Met/Lysine ratios in experimental diets

\begin{tabular}{|c|c|c|c|c|c|}
\hline & \multirow{2}{*}{$\begin{array}{c}\text { Positive } \\
\text { control } \\
\text { diet }\end{array}$} & \multicolumn{4}{|c|}{ Negative control diet (Low-protein diets) } \\
\hline & & $\begin{array}{c}\text { Non- } \\
\text { addition }\end{array}$ & $\begin{array}{l}100 \% \\
\text { TSAA }\end{array}$ & $\begin{array}{l}105 \% \\
\text { TSAA }\end{array}$ & $\begin{array}{l}110 \% \\
\text { TSAA }\end{array}$ \\
\hline \multicolumn{6}{|c|}{ Starter period (1-10 days of age) } \\
\hline TSAA/Lys ratio & 0.756 & 0.605 & 0.756 & 0.791 & 0.833 \\
\hline Met/Lys ratio & 0.512 & 0.294 & 0.539 & 0.574 & 0.618 \\
\hline \multicolumn{6}{|c|}{ Grower period (11-21 days of age) } \\
\hline TSAA/Lys ratio & 0.772 & 0.613 & 0.772 & 0.810 & 0.849 \\
\hline Met/Lys ratio & 0.496 & 0.299 & 0.528 & 0.567 & 0.606 \\
\hline
\end{tabular}

Table 4. Quantities of Met supplementation

\begin{tabular}{|c|c|c|c|c|c|}
\hline & \multirow{2}{*}{$\begin{array}{c}\text { Positive } \\
\text { control } \\
\text { diet }\end{array}$} & \multicolumn{4}{|c|}{ Negative control diet (Low-protein diets) } \\
\hline & & $\begin{array}{c}\text { Non- } \\
\text { addition }\end{array}$ & $\begin{array}{l}100 \% \\
\text { TSAA }\end{array}$ & $\begin{array}{l}105 \% \\
\text { TSAA }\end{array}$ & $\begin{array}{l}110 \% \\
\text { TSAA }\end{array}$ \\
\hline \multicolumn{6}{|l|}{ Starter period (1-10 days of age) } \\
\hline Additional Methionine $(\mathrm{g} / 100 \mathrm{~kg})$ & 409 & 0.00 & 486 & 538 & 601 \\
\hline Corn starch $(\mathrm{g} / 100 \mathrm{~kg})$ & 0.00 & 1,329 & 297 & 245 & 182 \\
\hline \multicolumn{6}{|l|}{ Grower period (11-21 days of age) } \\
\hline Additional Methionine $(\mathrm{g} / 100 \mathrm{~kg})$ & 293 & 0.00 & 370 & 419 & 469 \\
\hline Corn starch $(\mathrm{g} / 100 \mathrm{~kg})$ & 0.00 & 980 & 259 & 210 & 160 \\
\hline
\end{tabular}

At 42 days of age, after overnight feed deprivation, all chickens were weighed. Sixteen chickens (two chickens per pen) were randomly selected from each treatment group for sacrifice using $\mathrm{CO}_{2}$ asphyxiation for 1.5-2.0 min. Subsequently, the abdominal fat (including fat surrounding the gizzard, Cabel et al., 1987) of each bird was collected and weighed. The carcass yield of a broiler chicken was defined as the carcass without blood, feathers and giblets. Breast (without skin), wings, thighs and drumsticks (with skin) were weighted and expressed as a percentage of live weight. For body composition analysis, the whole body of a broiler chicken (including feathers, abdominal fat and blood) from each replication was ground by an industrial mincer and then homogenized by a blender twice. Twenty gram samples of the homogenate were collected into a zip-lock bag and stored at $-20^{\circ} \mathrm{C}$ until chemical analysis according to the method of AOAC (2000).

\section{Biochemical Analyses}

Liver lipid was measured according to the method of Sutton et al. (1984). The blood samples were centrifuged at 3,000 rpm for 15 minutes and the serum was decanted into aseptically treated vials. One gram of liver sample was taken and placed in a test tube with 5-fold ethanol: acetone $(1: 1 \mathrm{v} / \mathrm{v})$, then homogenized at 20,000 rpm for 1 minute, centrifuged at 3,000 rpm for 10 minutes and the supernatant was collected in vials. The samples were stored at $-20^{\circ} \mathrm{C}$ until further analyzed.

Serum and liver lipid samples were analyzed for triglyceride by enzyme colorimetric method (Test kits of Human Gesllschaft fur Biochemica und Diagnostica
mbH, Co., Ltd, Germany). Low density lipoprotein-cholesterol (LDL-C) was measured by enzyme colorimetric method (Test kits of Roche Diagnostics GmbH, USA).

The homogenized whole body composition was subsequently analyzed for moisture, crude protein, total ash and fat according to the standard procedures of AOAC (2000). While, gross energy in the whole body was analyzed by bomb calorimeter (e2k isothermal bomb calorimeter, CAL2k, Digital Data Systems, South Africa).

\section{Statistical Analysis}

This experiment had a completely randomized design (CRD) with eight replications. Data were analyzed with analysis of variance (ANOVA) procedure using the following model. Significant difference among the mean of groups was separated by Tukey's honestly significant difference test at a $5 \%$ probability level.

$$
\mathrm{Y}_{\mathrm{ij}}=\mu+\mathrm{A}_{\mathrm{i}}+\varepsilon_{\mathrm{ij}}
$$

When; $Y_{i j}$ is the observed response, $A_{i}$ is the effect of diets and $\varepsilon_{\mathrm{ij}}$ is the experimental error; $\varepsilon_{\mathrm{ij}} \sim \operatorname{NID}\left(0, \sigma^{2}\right)$.

\section{Results and Discussion}

\section{Growth Performance}

The effects of adding Met to low-protein diets during 121 days of age are given in Table 5. The body weight and FCR of the negative control group were significantly lower than those of other groups $(P<0.01)$, while adding Met to low-protein diets significantly improved the growth rate and FCR to levels similar to those of the positive control group. Feed intake in the low-protein diet with the $105 \%$ TSAA group was significantly higher than that of the positive and negative control groups $(P<0.05)$. 
Table 5. Effects of adding Met to low-protein diets on productive performance of broiler chicks during 1-21 days of age

\begin{tabular}{|c|c|c|c|c|c|}
\hline \multirow{2}{*}{ Item } & \multirow{2}{*}{ Positive control } & \multicolumn{4}{|c|}{ Low-protein } \\
\hline & & Negative control & $100 \%$ TSAA & $105 \%$ TSAA & $110 \%$ TSAA \\
\hline Initial body weight ( $\mathrm{g} /$ chick) & $43.86 \pm 0.49$ & $43.86 \pm 0.38$ & $43.86 \pm 0.41$ & $43.86 \pm 0.42$ & $43.86 \pm 0.39$ \\
\hline Body weight (g/chick) & $787.51 \pm 35.34^{\mathrm{A}}$ & $701.34 \pm 19.74^{\mathrm{B}}$ & $785.39 \pm 37.20^{\mathrm{A}}$ & $799.26 \pm 14.63^{\mathrm{A}}$ & $788.46 \pm 27.41^{\mathrm{A}}$ \\
\hline Body weight gain (g/chick) & $743.65 \pm 35.43^{\mathrm{A}}$ & $657.48 \pm 19.88^{\mathrm{B}}$ & $741.52 \pm 37.50^{\mathrm{A}}$ & $755.40 \pm 14.63^{\mathrm{A}}$ & $744.60 \pm 27.61^{\mathrm{A}}$ \\
\hline $\mathrm{ADG}(\mathrm{g} /$ chick $)$ & $35.41 \pm 1.69^{\mathrm{A}}$ & $31.31 \pm 0.95^{\mathrm{B}}$ & $35.31 \pm 1.78^{\mathrm{A}}$ & $35.97 \pm 0.69^{\mathrm{A}}$ & $35.46 \pm 1.31^{\mathrm{A}}$ \\
\hline Feed intake (g/chick) & $1024.89 \pm 22.23^{\mathrm{b}}$ & $1033.51 \pm 29.60^{\mathrm{b}}$ & $1057.44 \pm 44.42^{\mathrm{ab}}$ & $1070.57 \pm 9.65^{\mathrm{a}}$ & $1051.09 \pm 35.38^{\mathrm{ab}}$ \\
\hline Protein efficiency & $3.37 \pm 0.10^{\mathrm{B}}$ & $3.44 \pm 0.07^{\mathrm{B}}$ & $3.79 \pm 0.12^{\mathrm{A}}$ & $3.81 \pm 0.06^{\mathrm{A}}$ & $3.82 \pm 0.08^{\mathrm{A}}$ \\
\hline Protein intake (g/chick) & $220.35 \pm 4.78^{\mathrm{A}}$ & $191.20 \pm 5.48^{\mathrm{B}}$ & $195.63 \pm 8.22^{\mathrm{B}}$ & $198.05 \pm 1.78^{\mathrm{B}}$ & $194.45 \pm 6.54^{\mathrm{B}}$ \\
\hline FCR & $1.38 \pm 0.04^{\mathrm{B}}$ & $1.57 \pm 0.03^{\mathrm{A}}$ & $1.43 \pm 0.04^{\mathrm{B}}$ & $1.41 \pm 0.02^{\mathrm{B}}$ & $1.41 \pm 0.03^{\mathrm{B}}$ \\
\hline TSAA intake (g/chick) & $10.09 \pm 0.21^{\mathrm{B}}$ & $6.16 \pm 0.17^{\mathrm{C}}$ & $10.41 \pm 0.43^{\mathrm{B}}$ & $11.05 \pm 0.10^{\mathrm{A}}$ & $11.38 \pm 0.38^{\mathrm{A}}$ \\
\hline $\begin{array}{l}\text { Feed cost/body weight gain } \\
\text { (baht/kg) }\end{array}$ & $23.01 \pm 0.52^{\mathrm{AB}}$ & $23.50 \pm 0.26^{\mathrm{A}}$ & $22.72 \pm 0.53^{\mathrm{B}}$ & $22.70 \pm 0.52^{\mathrm{B}}$ & $22.49 \pm 0.42^{\mathrm{B}}$ \\
\hline Mortality rate $(\%)$ & $2.50 \pm 2.67$ & $0.00 \pm 0.00$ & $1.25 \pm 2.31$ & $1.87 \pm 2.58$ & $1.87 \pm 2.58$ \\
\hline
\end{tabular}

Mean \pm SD.

a and b Treatment means with different superscripts in the same row are significantly different $(P<0.05)$.

$\mathrm{A}, \mathrm{B}$ and $\mathrm{C}$ Treatment means with different superscripts in the same row are significantly different $(P<0.01)$.

Table 6. Effects of adding Met to low-protein diets during starter and subsequent re-feeding on growth performance of broiler chickens during 22-42 days of age

\begin{tabular}{|c|c|c|c|c|c|}
\hline \multirow{2}{*}{ Item } & \multirow{2}{*}{ Positive control } & \multicolumn{4}{|c|}{ Low-protein } \\
\hline & & Negative control & $100 \%$ TSAA & $105 \%$ TSAA & $110 \%$ TSAA \\
\hline Body weight gain (g/chicken) & $1875.41 \pm 47.04^{\mathrm{a}}$ & $1790.67 \pm 51.64^{\mathrm{b}}$ & $1835.27 \pm 55.64^{\mathrm{ab}}$ & $1837.82 \pm 63.56^{\mathrm{ab}}$ & $1829.17 \pm 48.29^{\mathrm{ab}}$ \\
\hline ADG ( $\mathrm{g} /$ chicken $)$ & $89.30 \pm 2.24^{\mathrm{a}}$ & $85.27 \pm 2.46^{\mathrm{b}}$ & $87.39 \pm 2.65^{\mathrm{ab}}$ & $87.51 \pm 3.03^{\mathrm{ab}}$ & $87.10 \pm 2.30^{\mathrm{ab}}$ \\
\hline Feed intake $(\mathrm{g})$ & $3448.18 \pm 102.65^{\mathrm{a}}$ & $3297.04 \pm 100.74^{\mathrm{b}}$ & $3408.86 \pm 80.41^{\mathrm{ab}}$ & $3376.90 \pm 53.27^{\mathrm{ab}}$ & $3379.57 \pm 103.62^{\mathrm{ab}}$ \\
\hline TSAA intake (g/chick) & $27.58 \pm \quad 0.82^{\mathrm{a}}$ & $26.37 \pm 0.80^{\mathrm{b}}$ & $27.27 \pm 0.64^{\mathrm{ab}}$ & $27.01 \pm 0.43^{\mathrm{ab}}$ & $27.04 \pm 0.83^{\mathrm{ab}}$ \\
\hline Protein intake $(\mathrm{g})$ & $655.15 \pm 19.50^{\mathrm{a}}$ & $626.44 \pm 19.14^{\mathrm{b}}$ & $647.68 \pm 15.28^{\mathrm{ab}}$ & $641.61 \pm 10.12^{\mathrm{ab}}$ & $642.12 \pm 19.69^{\mathrm{ab}}$ \\
\hline FCR & $1.84 \pm \quad 0.07$ & $1.84 \pm \quad 0.04$ & $1.86 \pm 0.04$ & $1.84 \pm 0.07$ & $1.85 \pm \quad 0.09$ \\
\hline Protein efficiency & $2.86 \pm 0.11$ & $2.86 \pm 0.07$ & $2.83 \pm 0.05$ & $2.86 \pm 0.11$ & $2.85 \pm 0.13$ \\
\hline $\begin{array}{l}\text { Feed cost/body weight gain } \\
\text { (baht } / \mathrm{kg} \text { ) }\end{array}$ & $29.25 \pm 1.12$ & $29.28 \pm 0.73$ & $29.54 \pm 0.58$ & $29.25 \pm 1.16$ & $29.40 \pm 1.38$ \\
\hline
\end{tabular}

Mean \pm SD.

$\mathrm{a}$ and $\mathrm{b}$ Treatment means with different superscripts in the same row are significantly different $(P<0.01)$.

The TSAA intakes of low-protein diets in the 105\% TSAA and $110 \%$ TSAA groups were higher than those in other groups. The protein intake of the positive control group was the highest $(P<0.01)$, while adding Met to lowprotein diets showed better protein efficiency rates (PER) than the positive and negative control groups $(P<0.01)$. Moreover, feed cost per body weight gain of the negative control group was the most expensive $(P<0.01)$. The mortality rate of chicks was not significantly different among the experimental groups $(P>0.05)$.

Growth performances of the chickens during the refeeding phase (22-42 days of age) are shown in Table 6. The negative control group still had significantly lower ADG, feed intake, TSAA intake and protein intake than the positive control group $(P<0.05)$, although adding Met to the low-protein diet groups showed no significant difference compared to the positive control group and the negative control group. FCR, PER and feed cost per body weight gain were also unaffected by dietary treatments $(P$
$>0.05)$.

Overall growth performances of chickens (1-42 days of age) are shown in Table 7. Body weight and ADG of the negative control group were significantly poorest $(P<$ 0.05 ), while adding Met to the low-protein diet groups significantly increased growth rates to levels similar to those of the positive control group. Feed intake was not significantly different among treatment groups $(P>0.05)$, although the negative control group tended to decrease feed intake compared to the positive control group and low-protein diet groups with 100 and $105 \%$ TSAA $(P=$ 0.07). TSAA intake was lower for the negative control group than for other groups $(P<0.01)$. Adding Met to the low-protein diet significantly improved the FCR of broiler chickens compared to the negative control group, and had better PER than the positive and negative control groups $(P<0.05)$. The feed costs per body weight gain of the chickens fed low-protein diets supplemented with Met were slightly lower than those of the positive and negative 
Table 7. Effects of adding Met to low-protein diets during starter and subsequent re-feeding on growth performance of broiler chickens during 1-42 days of age

\begin{tabular}{|c|c|c|c|c|c|}
\hline \multirow{2}{*}{ Item } & \multirow{2}{*}{ Positive control } & \multicolumn{4}{|c|}{ Low-protein } \\
\hline & & Negative control & $100 \%$ TSAA & $105 \%$ TSAA & $110 \%$ TSAA \\
\hline Body weight (g/chicken) & $2662.92 \pm 50.03^{\mathrm{A}}$ & $2492.01 \pm 55.14^{\mathrm{B}}$ & $2620.66 \pm 82.21^{\mathrm{A}}$ & $2637.08 \pm 60.44^{\mathrm{A}}$ & $2617.64 \pm 40.49^{A}$ \\
\hline Body weight gain (g/chicken) & $2619.05 \pm 49.87^{\mathrm{A}}$ & $2448.15 \pm 55.01^{\mathrm{B}}$ & $2576.80 \pm 82.57^{\mathrm{A}}$ & $2593.22 \pm 60.41^{\mathrm{A}}$ & $2573.78 \pm 40.73^{\mathrm{A}}$ \\
\hline ADG (g/chicken) & $62.36 \pm 1.19^{\mathrm{A}}$ & $58.29 \pm 1.31^{\mathrm{B}}$ & $61.35 \pm 1.97^{\mathrm{A}}$ & $61.74 \pm 1.44^{\mathrm{A}}$ & $61.28 \pm 0.97^{\mathrm{A}}$ \\
\hline Feed intake $(\mathrm{g})$ & $4473.07 \pm 115.39$ & $4330.55 \pm 121.65$ & $4466.30 \pm 102.82$ & $4447.47 \pm 50.62$ & $4430.66 \pm 129.40$ \\
\hline TSAA intake (g/chick) & $37.68 \pm 0.94^{\mathrm{A}}$ & $32.53 \pm 0.93^{\mathrm{B}}$ & $37.68 \pm 0.88^{\mathrm{A}}$ & $38.06 \pm 0.40^{\mathrm{A}}$ & $38.42 \pm 1.11^{\mathrm{A}}$ \\
\hline Protein intake $(\mathrm{g})$ & $875.51 \pm 22.28^{\mathrm{a}}$ & $817.64 \pm 23.00^{\mathrm{b}}$ & $843.31 \pm 19.38^{\mathrm{b}}$ & $839.67 \pm 9.63^{b}$ & $836.57 \pm 24.44^{\mathrm{b}}$ \\
\hline FCR & $1.71 \pm \quad 0.04$ & $1.77 \pm 0.04$ & $1.73 \pm 0.03$ & $1.71 \pm 0.05$ & $1.72 \pm \quad 0.05$ \\
\hline Protein efficiency & $2.99 \pm 0.08^{b}$ & $2.99 \pm 0.06^{\mathrm{b}}$ & $3.05 \pm 0.05^{\mathrm{ab}}$ & $3.09 \pm 0.08^{\mathrm{a}}$ & $3.08 \pm 0.09^{\mathrm{a}}$ \\
\hline $\begin{array}{l}\text { Feed cost/body weight gain } \\
\text { (baht/kg) }\end{array}$ & $27.46 \pm 0.58$ & $27.86 \pm \quad 0.57$ & $27.35 \pm 0.29$ & $27.01 \pm 0.51$ & $27.13 \pm 0.71$ \\
\hline
\end{tabular}

Mean \pm SD

a and $\mathrm{b}$ Treatment means with different superscripts in the same row are significantly different $(P<0.05)$.

${ }^{\mathrm{A} \text { and } \mathrm{B}}$ Treatment means with different superscripts in the same row are significantly different $(P<0.01)$.

control groups.

The low-protein induces an imbalance of the amino acid pattern in the diet (Saki et al., 2007). Azarnik et al. (2010) showed that the body weight at 21 days of the chicks fed a low-protein diet was significantly lower than that of the groups fed a higher protein diet. Since low TSAA intake depresses the feed intake and production performance of broiler chicks (Khajali et al., 2002; Bunchasak, 2009), adding Met clearly prevents this negative effect via improvement of the amino acid balance and increment of feed consumption (Takahashi et al., 1994). During 1-21 days of age, therefore, a close positive correlation between TSAA intake and body weight gain of broilers was found $(r=0.98)$, whereas the feed intake of the negative control was similar to that of the positive control group. However, Waldroup et al. (1976) stated that if a slight amino acid deficit exists, the chick will attempt to compensate by consuming more food, subsequently the growth rate may reach a maximum. In the current study, chicks fed the negative control diet have a lower Met consumption by about $40 \%$ and a lower growth rate by $11.5 \%$ compared to chicks fed the positive control diet. On the other hand, adding Met to a low-protein diet at $105 \%$ of the TSAA requirement resulted in a higher feed intake than the positive and negative control groups. Met deficiency at a level of around 60\% of the TSAA recommendation (negative control group) suppresses the growth rate without any effect on feed intake, which indicates that factors affecting and the mechanism controlling feed intake involved with Met supplementation are complicated.

PER is calculated from weight gain divided by the amount of protein consumed (weight gained/protein intake) and shows the direct effect of protein quality on growth rates (Mitchell et al., 1989). In this study, PER was improved in Met supplementation groups compared to the positive and negative control groups. Similarly, Bunchasak (1997) demonstrated that adding Met to a low-protein diet improved the feed efficiency and PER value of broiler chicks. This means that feeding a lowprotein diet supplemented with Met clearly promotes protein utilization better than feeding a low-protein diet alone. Additionally, feed costs per body weight gain in the Met supplementation groups tended to be decreased when compared with the positive control group. As long as feed intake is maintained by Met supplementation to the normal range, adding Met to low-protein diets may be a method of reducing the production cost of broiler chicks.

Focusing on the compensatory responses, during 22-42 days of age, it seems that chicks did not positively respond to the strategy of re-feeding by a conventional diet after feeding a low-protein diet with or without Met supplementation. Accordingly, Plavnik and Hurwitz (1990) showed that ad libitum feeding of a diet containing 9.4\% crude protein from 8 to 14 days decreased the feed intake of broilers by some $57 \%$ and $41 \%$ growth retardation, which was not recovered after 6 weeks of realimentation.

For the overall feeding period (1-42 days), the growth rate of the negative control group was significantly poorer than that of other groups, whereas adding Met to lowprotein diets still increased the growth rate and FCR to levels equal to those of the positive control group. Moreover, adding Met at the level of 105\% and 110\% TSAA requirement to a low-protein diet had significantly better PER and slightly lower feed cost/gain than positive and negative control diets. Since feeding a low-protein diet significantly depresses protein intake, this generally promotes better protein utilization (Hevia and Clifford, 1977; Cheng et al., 1997). Taniguchi et al. (2008) also demonstrated that adding Met to a $10 \%$ soybean protein isolate (SPI) diet improved PER from 2.28 to 2.97. After the re-feeding phase, feeding a low-protein diet supplemented with Met during starter-grower periods promotes protein utilization and lowers production cost compared to feeding a low-protein diet or a conventional diet alone. 
Table 8. Effects of methionine supplementation in low-protein diets on abdominal fat pad, lipoprotein and triglyceride in the liver and serum of broiler chicks at 21 days of age

\begin{tabular}{|c|c|c|c|c|c|}
\hline \multirow{2}{*}{ Item } & \multirow{2}{*}{ Positive control } & \multicolumn{4}{|c|}{ Low-protein } \\
\hline & & Negative control & $100 \%$ TSAA & $105 \%$ TSAA & $110 \%$ TSAA \\
\hline Liver weight $(\mathrm{g})$ & $21.02 \pm 1.40$ & $21.01 \pm 1.04$ & $21.06 \pm 2.22$ & $22.23 \pm 2.55$ & $22.55 \pm \quad 2.94$ \\
\hline Liver weight ( $\%$ of live weight) & $2.58 \pm 0.13$ & $2.90 \pm 0.18$ & $2.59 \pm 0.25$ & $2.72 \pm 0.31$ & $2.74 \pm \quad 0.35$ \\
\hline \multicolumn{6}{|l|}{ Liver } \\
\hline TG $(\mathrm{mg} / \mathrm{g})$ & $18.08 \pm 2.77$ & $15.95 \pm 2.26$ & $17.47 \pm 3.13$ & $15.03 \pm 1.82$ & $17.44 \pm \quad 2.84$ \\
\hline Abdominal fat pad ( $\%$ live weight) & $1.35 \pm 0.32^{\mathrm{b}}$ & $2.00 \pm 0.24^{\mathrm{a}}$ & $1.84 \pm 0.40^{\mathrm{a}}$ & $1.95 \pm 0.27^{\mathrm{a}}$ & $1.89 \pm \quad 0.61^{\mathrm{a}}$ \\
\hline \multicolumn{6}{|l|}{ Serum } \\
\hline $\mathrm{TG}(\mathrm{mg} / \mathrm{d} l)$ & $118.22 \pm 75.43^{\mathrm{B}}$ & $115.50 \pm 77.49^{\mathrm{B}}$ & $119.01 \pm 40.82^{\mathrm{B}}$ & $151.71 \pm 46.75^{\mathrm{AB}}$ & $203.90 \pm 109.66^{\mathrm{A}}$ \\
\hline LDL-C $(\mathrm{mg} / \mathrm{d} l)$ & $31.86 \pm 6.25^{\mathrm{A}}$ & $22.88 \pm 2.53^{\mathrm{B}}$ & $23.38 \pm 4.50^{\mathrm{B}}$ & $26.88 \pm 5.49^{\mathrm{AB}}$ & $24.50 \pm 3.78^{\mathrm{B}}$ \\
\hline
\end{tabular}

Mean \pm SD.

a and $b$ Treatment means with different superscripts in the same row are significantly different $(P<0.05)$.

${ }^{A}$ and $\mathrm{B}$ Treatment means with different superscripts in the same row are significantly different $(P<0.01)$.

\section{Fat Accumulation}

Measurements of abdominal fat pads, serum lipoprotein and triglyceride of chicks at 21 days of age are shown in Table 8. The weight of the abdominal fat pads of the low-protein diet groups (with or without Met supplementation) was significantly heavier than that of the positive control group $(P<0.05)$, while abdominal fat was slightly decreased by Met supplementation, and a negative correlation between TSAA intake and abdominal fat was found $(\mathrm{r}=-0.69)$. The liver of chicks fed the low-protein diet without Met supplementation seems to be bigger than that of other groups. Liver triglyceride level was not significantly affected by the treatments, but a negative correlation between liver weight (\% live weight) and liver triglyceride level $(\mathrm{r}=-0.62)$ was found. The serum LDL-C level of the positive control group was significantly increased $(P<0.05)$ compared to that of other groups except for the 105\% TSAA group.

Abdominal fat constitutes approximately $2-3 \%$ of the broiler live weight (Leenstra, 1986). Sex, age, feed efficiency, genotype and feeding are some of the main factors affecting abdominal fat in broilers. In the present study, the weight of abdominal fat pads of the chicks fed lowprotein diets (with Met and without Met) was higher than that of the positive control group. According to Yamazaki et al. (2006) who demonstrated that chicks fed low-protein and amino acid supplemented diets had significantly increased abdominal fat weight compared to that of chicks fed a control diet. Aletor et al. (2000) and Faria Filho (2003) indicated that decreasing dietary protein generally increases the relative weights of the abdominal fat to body weight. This phenomenon may be due to high feed intake or less energy used for protein synthesis. According to several investigators, feeding low-protein with amino acid supplementation increases feed consumption, and consequently increases carcass fat deposition (Rosebrough and Steele, 1985). Moreover, the negative control group in our study had a higher energy: protein ratio than that of the positive control group. Diets with a high energy: protein ratio promote energy retention as fat
(Kamran et al., 2008). One possible interpretation is that a high energy/protein ratio forces over-consumption of dietary energy, in order to meet the protein and amino acid requirements. Conversely, diets with a low calorie/ protein ratio are believed to decrease carcass fat, because broilers consume less energy in order to meet the protein requirements (Aletor et al., 2000). Another reason is that chicks fed a low-protein diet need less energy for nitrogen excretion as uric acid and provide more energy for lipid synthesis (Bartov, 1979). Adding Met to low-protein diets may promote growth performance and protein utilization, but high fat accumulation still remains. Therefore, supplementing low-protein diets with Met until the market weight is reached may be inappropriate because high fat deposition in the carcass is not wanted by consumers.

Lipogenesis mainly occurs in the liver of poultry. Aletor et al. (2000) reported that decreasing dietary protein increased liver weight, which might be caused by high activities of lipogenetic enzymes. Focusing on the effect of Met, Takahashi and Akiba (1995) reported that supplementing $0.93 \%$ of TSAA in the corn soybean mealglutamic acid diet decreased the activity of malic enzyme, which is closely related with lipogenesis in the liver. Austic (1985) also showed that Met deficiency in the diet increased abdominal fat deposition and malic enzyme activity in the liver. The results of the present study show a low-protein diet deficient in Met tended to increase liver weight ( $\%$ of body weight) and high abdominal fat accumulation was found. Conversely, adding Met to lowprotein diets tended to reduce the liver weight, consequently a negative correlation between TSAA intake and liver weight per body weight gain was found $(r=-0.63)$. The decrease in liver weight (as \% of body weight) may be attributed to balanced amino acids by Met supplementation, since amino acid imbalance stimulates protein metabolism in the liver or increased rate of amino acid synthesis in order to provide sufficient amino acids (Hiramoto et al., 1990).

There was no significant difference in the triglyceride content in the liver among the experimental groups. In 
Table 9. Effects of methionine supplementation in low-protein diets during starter and grower periods and subsequent re-feeding on the body composition of broiler chickens at 42 days of age

\begin{tabular}{lrrrrr}
\hline \hline \multirow{2}{*}{ Item } & Positive control & \multicolumn{4}{c}{ Low-protein } \\
\cline { 3 - 6 } & & Negative control & $100 \%$ TSAA & $105 \%$ TSAA & $110 \%$ TSAA \\
\hline Moisture $(\%)$ & $65.19 \pm 1.16$ & $65.38 \pm 1.75$ & $64.77 \pm 1.94$ & $64.61 \pm 1.53$ & $65.16 \pm 1.83$ \\
Gross energy (kcal/g) & $6.03 \pm 0.08$ & $5.98 \pm 0.14$ & $6.00 \pm 0.24$ & $5.99 \pm 0.09$ & $5.97 \pm 0.13$ \\
Total ash $(\%)$ & $2.43 \pm 0.14$ & $2.47 \pm 0.24$ & $2.49 \pm 0.30$ & $2.49 \pm 0.24$ & $2.56 \pm 0.21$ \\
Fat $(\%)$ & $14.32 \pm 0.80$ & $13.73 \pm 0.62$ & $14.42 \pm 0.91$ & $13.68 \pm 1.06$ & $13.46 \pm 0.42$ \\
Protein $(\%)$ & $18.09 \pm 0.59$ & $17.79 \pm 0.85$ & $18.22 \pm 0.89$ & $18.44 \pm 0.77$ & $17.85 \pm 1.12$ \\
\hline
\end{tabular}

Mean \pm SD.

poultry, triglyceride is synthesized in the liver and transported by the blood system and then taken up into adipose cells by lipoprotein lipase (Bunchasak et al., 1997). High triglyceride content in the liver could be caused by a nutrition imbalance such as low-protein, high energy, amino acid imbalance and amino acid deficiency (Griffith et al., 1969), lipotropic (Met, choline and vitamin $B_{12}$,) deficiency (Chen et al., 1993). In laying hen studies, triglyceride and lipid in the liver were increased by supplementing the diet with Met (Bunchasak and Silapasorn, 2005). Therefore, the effect of Met on the fat metabolism of immature birds (during starter period of broiler chicks) may be different from that of mature birds (laying hens), since laying hens need more fat synthesis to support egg production (fat accumulation in yolk), which involves the activity of the hormone estrogen.

Triglyceride is produced by the esterification process of acyl-CoA and glycerol-3-phosphate in the liver, and then transported via blood circulation to extra-hepatic tissue by lipoprotein (Hermier et al., 1984). Apart from de novo lipogenesis, fat deposition in adipose tissue depends on a change in the relative activity of lipoprotein lipase, which mediates the uptake of fatty acid from the blood and of hormone sensitive lipase, which mediates the output of fatty acid from adipose tissue (Paik and Yearick, 1978). Adding Met to a low-protein diet linearly increased the triglyceride concentration in serum $(r=0.86)$ and a positive correlation between TSAA intake and serum triglyceride level $(r=0.64)$ was also found.

The turnover rates of plasma cholesterol and LDL-C are higher in chickens fed a high protein diet compared with those fed a low-protein diet (Yeh and Leveille, 1973). In our study, the serum LDL-C level in chicks fed a high protein diet was higher than that in those fed low-protein diet, while serum LDL-C was decreased by Met supplementation, while positive correlation between TSAA intake and serum LDL-C levels was found $(r=0.63)$ among low-protein supplemented with Met groups.

\section{Body Composition}

Whole body compositions of broiler chickens after the re-feeding phase (at 42 days of age) are presented in Table 9. Dietary treatments did not significantly affect the moisture, gross energy, total ash, fat and protein in the whole body of broiler chickens $(P>0.05)$.
The body composition of broilers is affected by many factors such as strain, age, sex, quality and quantity of the dietary protein and energy, slaughter, sampling method and environmental conditions (Koide and Ishibashi, 1995). Our study indicates that the experimental diets had no effects on the whole body composition of broiler chickens after the re-feeding phase. Nevertheless, the groups with added Met tended to have decreased whole body fat. According to Bunchasak (1997) who reported that carcass compositions of broiler chicks showed no significant difference by adding Met to low-protein diets after the re-feeding period. An additional study, Auckland and Morris (1971) demonstrated that turkeys fed lower protein diets during the early rearing period resulted in weight gain and carcass composition similar to that of control-fed birds at 20 weeks of age. Pokniak and Cornejo (1982) reported no significant difference in body composition between previously restricted and full-fed chickens at 8 weeks of age. The study of Priemnguluam (2000) also reported that adding Met to low-protein diets during the starter period did not affect the whole body composition of broiler chickens after the re-feeding phase, although abdominal fat pads during the starter period were increased. This indicates that reducing the protein intake with Met supplementation during the starter-grower period followed by re-feeding with a conventional diet induces changes in the chemical composition of the bodies of chicks similar to the case of feeding a conventional diet throughout the experimental period.

\section{Carcass Qualities}

Carcass qualities of broiler chicks at 42 days of age are shown in Table 10. After the re-feeding phase, the carcass yield, outer breast, inner breast and wings of the $110 \%$ TSAA group were significantly higher than those of the negative control group $(P<0.05)$. However, dietary treatments did not significantly affect the thighs, drumsticks and abdominal fat $(P>0.05)$.

Since no significant compensatory response was shown during the re-feeding phase, the carcass and breast meat yields of the negative control group were still inferior to those of the other groups, which is in agreement with the findings of the study of Moran (1979), while the group of chickens fed 110\% TSAA had higher breast meat yield than the negative control group and equal breast meat 
Table 10. Effects of Met supplementation in low-protein diets during starter and grower periods on carcass quality and abdominal fat of broiler chickens at 42 days of age

\begin{tabular}{lccccc}
\hline \multirow{2}{*}{\multicolumn{1}{c}{ Item }} & Positive control & \multicolumn{3}{c}{ Low-protein } \\
\cline { 3 - 6 } & & Negative control & $100 \%$ TSAA & $105 \%$ TSAA & $110 \%$ TSAA \\
\hline Carcass yield (\%) & $77.99 \pm 1.49^{\mathrm{ab}}$ & $76.56 \pm 1.01^{\mathrm{b}}$ & $77.53 \pm 0.87^{\mathrm{ab}}$ & $76.87 \pm 1.51^{\mathrm{ab}}$ & $78.57 \pm 1.16^{\mathrm{a}}$ \\
Outer breast $(\%)$ & $14.63 \pm 1.52^{\mathrm{a}}$ & $12.58 \pm 1.06^{\mathrm{b}}$ & $14.06 \pm 1.55^{\mathrm{ab}}$ & $14.15 \pm 0.59^{\mathrm{ab}}$ & $15.24 \pm 1.14^{\mathrm{a}}$ \\
Inner breast (\%) & $3.68 \pm 0.33^{\mathrm{ab}}$ & $3.30 \pm 0.25^{\mathrm{b}}$ & $3.71 \pm 0.32^{\mathrm{ab}}$ & $3.47 \pm 0.14^{\mathrm{ab}}$ & $3.75 \pm 0.37^{\mathrm{a}}$ \\
Thigh (\%) & $12.27 \pm 1.44$ & $11.51 \pm 0.74$ & $11.92 \pm 0.76$ & $11.57 \pm 1.42$ & $12.39 \pm 1.05$ \\
Drumstick (\%) & $9.99 \pm 0.69$ & $9.16 \pm 0.63$ & $9.31 \pm 0.63$ & $9.41 \pm 0.74$ & $9.89 \pm 0.51$ \\
Wing (\%) & $7.63 \pm 0.48^{\mathrm{a}}$ & $6.98 \pm 0.19^{\mathrm{b}}$ & $7.40 \pm 0.39^{\mathrm{ab}}$ & $7.50 \pm 0.45^{\mathrm{ab}}$ & $7.71 \pm 0.38^{\mathrm{a}}$ \\
Abdominal fat $(\%)$ & $2.01 \pm 0.29$ & $2.05 \pm 0.32$ & $2.08 \pm 0.47$ & $2.18 \pm 0.29$ & $2.15 \pm 0.48$ \\
\hline
\end{tabular}

Mean \pm SD.

$\mathrm{a}$ and $\mathrm{b}$ Treatment means with different superscripts in the same row are significantly different $(P<0.05)$.

yield to the positive control group. This indicates that high TSAA intake $(110 \%$ TSAA group; TSAA intake $=$ $38.42 \mathrm{~g} /$ chick) produces high breast meat yield of broilers. A positive correlation between TSAA intake and outer breast meat yield was found $(\mathrm{r}=0.91)$. Accordingly, Moran (1994) reported that sulfur amino acid increased the mass of breast meat yield more than that of other amino acids. The study of Saki et al. (2007) demonstrated that Met supplementation (120\% of NRC recommendation, 0.46 and $0.38 \%$, at starter and grower stage) in a low-protein diet improved carcass quality and breast meat of broilers. Several investigators have also reported that excess Met level in the diet elevates breast meat yield (Schutte and Pack, 1995; Hickling et al. 1990).

The abdominal fat pads of broiler chickens at 42 days of age (Table 10) showed no significant difference among treatments, in contrast to the results at 21 days of age (Table 8). Abdominal fat may not be a good index of carcass fatness in male broilers (Rosebrough and Steele, 1985), but the results of fat accumulation in the whole body also show no significant difference among treatment groups after the re-feeding phase (Table 9). Although no compensatory response in terms of growth performance was shown, it is clear that fat accumulation was reduced after the re-feeding phase.

We suggest that feeding a low-protein diet with Met supplementation at $105 \%$ or $110 \%$ of the TSAA requirement during the starter-grower period and subsequent re-feeding is an effective tool for improving broiler chicken production.

\section{Acknowledgments}

We are grateful to Sumitomo Chemical Co., Ltd., Japan for supplying funding and the methionine and also to the staff of the Department of Animal Science, Kasetsart University, Thailand.

\section{References}

Aletor VA, Hamid II, Nied E and Pfeffer E. Low protein amino acid supplemented diets in broiler chickens: effects on performance, carcass characteristics, whole-body composition and efficiencies of nutrient utilization. Journal of the Science of Food and Agriculture, 80: 541-554. 2000.

AOAC. Official Method of Analysis, $17^{\text {th }}$ ed. Association of Official Agricultural Chemists, Washington, DC. 2000.

Auckland JN and Morris TR. Compensatory growth in turkeys: effect of undernutrition on subsequent protein requirements. British of Poultry Science, 12: 41-48. 1971.

Austic RE. Feeding poultry in hot and cold climates. In: Physiology in Livestock (Youssef MK Ed.). pp. 123-136. CRC Press. Boca Raton. FL. 1985.

Azarnik A, Bokarpour M, Eslami M, Ghorbani MR and Mirzadeh $\mathrm{K}$. The effect of different levels of diet protein on broilers performance in ad libitum and feed restriction method. Journal of Animal and Veterinary Advances, 9: 631-634. 2010.

Bartov I. Nutritional factors affecting quantity and quality of carcass fat in chickens. Federation Proceedings, 38: 26272630. 1979.

Bunchasak, C. The effect of supplementing sulfur amino acid to a low-protein diet on growth performance and fat accumulation of broiler chicks. Ph.D. Gifu University. 1997.

Bunchasak C. Role of dietary methionine in poultry production. Journal of Poultry Science, 46: 169-179. 2009.

Bunchasak C, Santoso U, Tanaka K, Ohtani S and Collado CM. The effects of supplementing methionine plus cystine to a low-protein diet on the growing broiler chicks. AsianAustralasian Journal of Animal Science, 10: 185-191. 1997.

Bunchasak C and Silapason T. Effects of adding methionine in low protein diet on production performance, reproductive organs and chemical liver composition of laying hens under tropical conditions. International Journal of Poultry Science, 5: 301-308. 2005.

Cabel MC, Goodwin TL and Waldroup PW. Reduction in abdominal fat content of broiler chickens by the addition of feather meal to finisher diets. Poultry Science, 66: 16441651. 1987.

Cauwenberghe SV and Burnham D. New developments in amino acid and protein nutrition of poultry, as related to optimal performance and reduced nitrogen excretion. $13^{\text {th }}$ European Symposium Poultry Nutrition. Blankenberg, Belgium. 2001.

Chen F, Noll SL, Waibel PE and Hawkins DM. Effect of folate, vitamin $\mathrm{B}_{12}$ and choline supplementation on turkey breeder performance, Poultry Science, 72: (Suppl. 1): 72 (Abstr.). 1993.

Cheng TK, Hamre ML and Coon CN. Responses of broilers to dietary protein levels and amino acid supplementation to 
low-protein diets at various environmental temperatures. Journal of Applied Poultry Research, 6: 18-33. 1997.

Faria Filho DE, Rosa PS, Vieira BS, Macari M and Furlan RL. Protein levels and environmental temperature effects on carcass characteristics, performance and nitrogen excretion of broiler chickens from 7 to 21 days of age. Brazilian Journal of Poultry Science, 7: 247-253. 2003.

Griffith M, Olinde AJ, Schexnailder R, Davenport RF and Mcknight WF. Effect of choline, methionine and vitamin $B_{12}$ on liver fat, egg production and egg weight in hens. Poultry Science, 48: 2160-2172. 1969.

Hermier D, Chapman MJ and Leclercq B. Plasma lipoprotein profile in fasted and refed chickens selected for high or low adiposity. Journal of Nutrition, 114: 1112-1121. 1984.

Hevia P and Clifford AJ. 1977. Protein intake, uric acid metabolism and protein efficiency ratio in growing chicks. Journal of Nutrition, 107: 959-964. 1977.

Hickling D, Geuenter W and Jackson ME. The effects of dietary methionine and lysine on broiler chicken performance and breast meat yield. Canadian Journal of Animal Science, 70: 673-678. 1990.

Hiramoto K, Muramatsu T and Okumura J. Effect of methionine and lysine deficiencies on protein synthesis in the liver and oviduct and in the whole body of laying hens. Poultry Science, 69: 84-89. 1990.

Hussein AS, Cantor AH, Pescatore AJ, Gates RS, Burnham D, Ford MJ and Paton ND. Effect of low protein diets with amino acid supplementation on broiler growth. Journal of Applied Poultry Research, 10: 354-362. 2001.

Jianlin SI, Kersey JH, Fritts CA and Waldroup PW. An evaluation of the interaction of lysine and methionine in diets for growing broiler. International Journal of Poultry Science, 3: 51-60. 2004.

Kalinowski A, Moran ET and Wyatt CL. Methionine and cystine requirement of slow and fast-feathering broiler males from zero to three weeks of age. Poultry Science, 82: 1423-1427. 2003.

Kamran Z, Sarwar M, Nisa M, Nadeem MA, Mahmood S, Babars ME and Ahmed S. Effect of low-protein diets having constant energy to protein ratio on performance and carcass characteristics of broiler chickens from one to thirty-five day of age. Poultry Science, 87: 468-474. 2008.

Keshavarz K and Austic RE. The use of low-protein, lowphosphorus, amino acid and phytase supplemented diets on laying hen performance and nitrogen and phosphorus excretion. Poultry Science, 83: 75-83. 2004.

Khajali F and Moghaddam N. Methionine Supplementation of Low Protein Broiler Diets: Influence upon Growth Performance and Efficiency of Protein Utilization. International Journal of Poultry Science, 5: 569-573. 2006.

Khajali F, Moghaddam N, Mesgaran MD and Shareghi B. Growth performance and efficiency of nitrogen utilization of broilers as affected by methionine deficiency. Iranian Journal of Agricultural Science and Nature Resource, 9: 193204. 2002.

Koide $\mathrm{K}$ and Ishibashi $\mathrm{T}$. Threonine requirement in female broilers affected by dietary amino acid levels. Japanese Poultry Science, 30: 31-39. 1995.

Leenstra FR. Effect of age, sex, genotype and environment on fat deposition in broiler chickens. World's Poultry Science Journal, 42: 12-25. 1986.

Leeson S and Summers JD. Feeding programs for broilers and broiler breeders, In: Commercial Poultry Nutrition. pp. 161. University Books. Guelph. Ontario. 1991.
Mitchell GV, Jenkins MY and Grundel E. Protein efficiency ratios and net protein ratios of selected protein foods. Plant Foods for Human Nutrition, 39: 55-58. 1989.

Moran ETJr. Carcass quality changes with broiler chickens after dietary protein restriction during the growing phase and finishing period compensatory growth. Poultry Science, 58: 1257-1270. 1979.

Moran ET Jr. Responses of broiler strains differing in body fat to inadequate methionine: live performance and processing yields. Poultry Science, 73: 1116-1126. 1994.

Paik HS and Yearick ES. Influence of dietary and meal frequency on lipoprotein lipase and hormone sensitive lipase in rat adipose tissue. Journal of Nutrition, 108: 179-185. 1978.

Plavnik I and Hurwitz S. Performance of broiler chickens and turkey poults subjected to feed restriction or feeding of low-protein or low-sodium diets at an early age. Poultry Science, 69: 945-952. 1990.

Pokniak I and Cornejo SB. Effects of energy and protein under nutrition on productive performance and carcass, liver and digestive tract composition of broiler males. Nutrition Reports International, 26: 319-327. 1982.

Priemnguluam C. Effects of sulfur amino acid supplementation in low protein diet on growth performance and carcass quality in broiler chicks. M.S. Thesis, Kasetsart University. 2000.

Rosebrough RW and Steele NC. Energy and protein relationship in broilers.1. Effect of protein levels and feeding regimens on growth, body composition and in vitro lipogenesis of broilers chick. Poultry Science, 64: 126-199. 1985.

Saki AA, Mohammad Pour HA, Ahmdi A, Akhzar MT and Tabatabie MM. Decreasing broiler crude protein requirement by methionine supplementation. Pakistan Journal of Biological Sciences, 10: 757-762. 2007.

Schutte JB and Pack M. Sulfur amino acid requirement of broiler chick from fourteen to thirty-eight days of age. 1. Performance and carcass yield. Poultry Science, 74: 480-487. 1995.

Sutton CD, Muir WM and Mitchell GE. Cholesterol metabolism in the laying hen as influenced by dietary cholesterol, caloric intake and genotype. Poultry Science, 63: 972-980. 1984.

Takahashi K and Akiba Y. Effect of methionine supplementation on lipogenesis and lipolysis in broiler chicks. Japanese Poultry Science, 32: 99-106. 1995.

Takahashi K, Konashi S, Akiba Y and Horiguchi M. The effects of dietary methionine and dispensable amino acid supplementation on abdominal fat deposition in male broiler. Animal Science and Technology (Japan), 65: 244-250. 1994.

Taniguchi M, Nagao K, Inoue K and K Imaizumi. Cholesterol lowing effect of sulfurcontaining amino acids added to soybean protein diet in rats. Journal of Nutrition Science, 54: 448-453. 2008.

Waldroup PW, Mitchell RJ, Rayne JR and Hazen KR. Performance of chicks fed diets formulated to minimize excess levels of essential amino acid. Poultry Science, 55: 243-253. 1976.

Yamazaki M, Murakami H and Nakashima K. Effect of excess essential amino acid in low protein diet on abdominal fat deposition and nitrogen excretion of the broiler chicks. Journal of Poultry Science, 43: 150-155. 2006.

Yeh SJC and Leveille GA. Significance of skin as site of fatty acid and cholesterol synthesis in the chick. Proceedings of the Society for Experimental Biology and Medicine, 142: 115. 1973.

Zubair AK and Leeson S. Compensatory growth in the broiler chicken: a review. World's Poultry Science Journal, 52: 189-201. 1996. 